\author{
Patryk TOMALA \\ patryk.tomala@outlook.com
}

\title{
ODKRYWANIE TAJSKOŚCI - WICHIT WATHAKAN I POWSTANIE TAJSKIEJ TOŻSAMOŚCI NARODOWEJ
}

\section{ABSTRACT Discovering Thainess - Wichit Wathakan and Creation of Thai National Identity \\ 'Thainess' is a term deeply ingrained into political discourse of Kingdom of Thailand. Politicians from different camps and parties use it to this day. This quite new concept was defined by Wichit Wathakan, who created a political philosophy around it. His works set a tone of discussion about the nation and the state in Thailand back in the 1930s. His concepts are still alive and well, and also more apparent than those proposed by his opponents. This article explains reasons of emerging of nationalism in Thailand and Thai nationalism, as well as character of both of them.}

KEYWORDS Thailand, Thai, Wichit, National Identity, Nation Building 


\section{WSTĘP}

Zagadnienie „tajskości” i kreowanie narodu tajskiego są tematami obecnymi w dyskursie publicznym Tajlandii od blisko stu lat. Wbrew pozorom nie tracą one na znaczeniu - np. kampania marketingowa Tourism Authority of Thailand na 2015 r. brzmiała 2015 Discover Thainess ${ }^{1}$, w samym tytule odnosząc się do pojęcia „tajskości”. Miała ona za zadanie ukazanie tajskości czy też wyróżniajacych cech narodu tajskiego i jego wyjątkowej kultury ${ }^{2}$. Władze Tajlandii dążą do aktywnego kreowania kształtu i charakteru tajskiego narodu. W 2014 r. przywódca wojskowej junty, która obaliła demokratycznie wybrany rząd Yingluck Shinawatry, generał Prayuth Chan-ocha, ogłosił Dwanaście naczelnych zasad dla silnej Tajlandii. Brzmią one następująco:

Tajowie powinni:

1. Podtrzymywaí trzy gtówne filary [państwa]: Naród, Religię i Monarchię.

2. Być uczciwi, sktonni do poświęceń i cierpliwi, wykazując się pozytywnym stosunkiem do dobra publicznego.

3. Być wdzięczni swym rodzicom, opiekunom i nauczycielom.

4. Dązyć do wiedzy i edukacji - bezpośrednio i pośrednio.

5. Dbać o umitowane tajskie tradycje.

6. Podtrzymywać moralność i spójnosśc oraz życzyć dobrze sobie nawzajem, jak również być hojni wobec innych.

7. Rozumieć i uczyć sie prawdziwej istoty ideatów demokracji z Jego Wysokościa Królem jako Gtowa Państwa.

8. Być zdyscyplinowani, szanować prawo, starszych i przetożonych.

9. Swiadomie i umyślnie przestrzegać dekretów królewskich Jego Wysokości Króla.

10. Stosować się do ekonomii wystarczalności Jego Wysokości Króla, oszczędzać pieniadze na wszelki wypadek, być ostrożni z dzieleniem się nadwyżkami pieniężnymi bądź ich inwestowaniem.

11. Zachowywać zdrowie psychiczne i fizyczne, nie poddawaí się mrocznym sitom namiętności, żywić uczucia wstydu i winy za grzechy, w zgodzie z zasadami religijnymi.

12. Stawiać dobro publiczne i narodowe ponad wtasnymi interesami ${ }^{3}$.

Powyższe reguły zostały opublikowane jako oficjalne zasady państwa i narodu tajskiego. Uczniowie są zobowiązani nauczyć się ich na pamięć i deklamować je codziennie w szkole ${ }^{4} \mathrm{Na}$ ich podstawie wyprodukowana została seria krótkich filmów, które

Thailand to Celebrate „2015 Discover Thainess” Campaign with Grand Opening Celebration, „TAT News", 5 I 2015, [online] http://www.tatnews.org/thailand-to-celebrate-\%E2\%80\%9C2015-discover-thainess\%E2\%80\%9D-campaign-with-grand-opening-celebration, 15 III 2016. Tłumaczenia wszystkich anglojęzycznych źródeł wykorzystanych w niniejszym artykule pochodzą od autora.

2 Tamże.

3 The Twelve Core Values for a Strong Thailand, National News Bureau of Thailand, [online] http:// nwnt.prd.go.th/link/en/Core_Values, 15 III 2016.

4 Thai Students Required to Recite Prayuth's 12 Core Values Daily, „Asian Correspondent”, 22 IX 2014, [online] https://asiancorrespondent.com/2014/09/all-thai-students-required-to-recite-daily-prayuths12-core-values, 15 III 2016. 
mają zaznajomić społeczeństwo Tajlandii z zasadami, którymi według junty generała Prayutha powinno się ono kierować w życiu. Zatytułowano je Thai Niyom, czyli Tajska Duma ${ }^{5}$. Junta nie jest nowatorska w swych staraniach. Jak już wspomniano, kształtowanie tajskości i kreowanie narodu tajskiego są procesami, których początki sięgają przełomu XIX i XX w. Przybrały one na sile po rewolucji 1932 r., kiedy doszło do obalenia absolutyzmu i wprowadzenia ograniczonego parlamentaryzmu.

Celem niniejszego artykułu jest rozważanie przyczyn zaistnienia owych procesów, jak również odpowiedź na pytanie o to, jak były one artykułowane przez głównego ideologa czasu rządów generała Plaeka Phibunsongkhrama (dalej nazywanego Phibunem $^{6}$ ), generała Luanga Wichita Wathakana (Wichita). Położył on podwaliny pod tajską tożsamość narodową i wydatnie przyczynił do jej wykreowania. To właśnie jego idee i koncepcje stanowią główny przedmiot rozważań w artykule. Sprawa ich implementacji (za co był odpowiedzialny Phibun) to temat równie zajmujący, aczkolwiek na tyle rozległy, że zasługuje na oddzielne opracowanie.

Wcześniej należy bliżej przyjrzeć się dwóm pojęciom kluczowym do rozpatrywania interesującej autora kwestii. Pierwszym z nich będzie tożsamość narodowa (tajskość stanowi przejaw tajskiej tożsamości narodowej), drugim - nation building (budowanie narodu), czyli proces kreacji owej tożsamości narodowej. Zagadnieniom tym poświęcone są dwie pierwsze części artykułu. W części trzeciej opisano główne założenia nacjonalizmu Wichita oraz uwarunkowania społeczno-polityczne, które stanowiły tło rozwoju jego ideologii.

\section{ZAGADNIENIA TEORETYCZNE - TWORZENIE NARODU I NACJONALIZM}

Zagadnienie budowania narodu jest tak stare, jak sama refleksja nad istnieniem wspólnot narodowych. Wczesne przemyślenia europejskich uczonych są szczególnie istotne w rozpatrywaniu źródeł tajskiego nacjonalizmu, gdyż Wichit Wathakan w trakcie swego pobytu w Europie miał okazję dogłębnie się z nimi zaznajomić.

Dziewiętnastowieczny niemiecki historyk i myśliciel Heinrich von Treitschke twierdził, że istnieją dwie przeciwne sobie tendencje. Z jednej strony państwa starają się ujednolicić swoją populację pod względem języka i kultury, a z drugiej narody dążą do utworzenia własnych państw ${ }^{7}$. Treitschke wierzył, że starcie między dążeniami narodowymi do samostanowienia a państwowymi do homogenizacji to constans. Jednocześnie państwo może (a wręcz powinno) dążyć do stworzenia jednego narodu $\mathrm{z}$ wielu, nad którymi panuje. Myśliciel twierdził, że „naturalne więzy krwi”, które określają naród, moga być „realne lub umowne”, gdyż „pod tym względem narody karmiq

The Twelve Core Values...

6 W języku tajskim do określania ważnych figur historycznych i publicznych używa się z reguły ich imienia bądź pseudonimu pochodzącego od nazwiska.

$7 \quad$ P. Lawrence, Nacjonalizm. Historia i teoria, przeł. P. K. Frankowski, Warszawa 2007, s. 37. 
się przedziwnymi ztudzeniami’s. Rozważania te są głęboko osadzone w rzeczywistości politycznej Niemiec okresu zjednoczenia, lecz równie dobrze pasują do sytuacji w Syjamie w pierwszej połowie XX w. W obu przypadkach występowała wielość różnorodnych grup charakteryzujących się silną odrębnością etniczną i językową (a więc, według Treitschkego, narodów, które miały dążyć do niepodległości), przy jednoczesnym istnieniu silnego ośrodka państwowego, zmierzającego do utworzenia ponad ową różnorodnością jednej centralnej tożsamości narodowej, ściśle związanej z owym państwem.

W innym duchu na temat budowania narodów wypowiadał się pochodzący z drugiej strony Renu Ernest Renan. Odróżniał on kategorię rasy, mającej wspólne podłoże etnolingwistyczne, od narodu, któremu przysługiwała suwerenność. Naród miał powstawać przez „konwergencję" różnych populacjį, a pojęcie rasy było w jego opinii mało istotne - ważniejsza jest wiara w spójność etniczną niż faktyczna spójnośćc ${ }^{10}$. Renan przedstawiał naród jako wspólnotę woluntarystyczną, w której istotniejsze od kategorii rasowych, językowych czy geograficznych są wspólne bogate dziedzictwo wspomnień i pragnienie zycia razem $^{11}$.

Nie sposób pisać na temat narodów i nacjonalizmu bez wspomnienia o Erneście Gellnerze i jego twierdzeniu, że to nie narody tworzą nacjonalizm, a nacjonalizm tworzy narody ${ }^{12}$. Powstawanie narodów i występowanie nacjonalizmu są $\mathrm{w}$ jego opinii związane z procesami modernizacyjnymi i industrializacją ${ }^{13}$. Teza ta była w kontrze do twierdzenia Eliego Kedouriego, który pisał, że nacjonalizm jest logicznie i socjologicznie przypadkowy, a zatem nie jest stanem naturalnym dla ludzkości i nie musiał się pojawic ${ }^{14}$. Gellner wskazywał, że w okresie feudalnym elity rządzące posiadały inną kulturę i posługiwały się innym językiem niż ich poddani. Jedyną istotną zależnością była ta regulująca korzyści, które obie strony sobie nawzajem zapewniały. Rządzący oferowali rządzonym bezpieczeństwo, w zamian domagali się żywności i innych dóbr materialnych od lokalnych, zróżnicowanych społeczności. Sytuację odwróciła modernizacja, która zatarła granicę między obiema grupami i wymusiła, aby granice kulturowe i polityczne pokrywaty się ze sobą, głównie za sprawą upowszechnienia się edukacji, która doprowadziła do homogenizacji kultury i języka w ramach danych państw ${ }^{15}$. Edukację opartą na kontekście narodowym Gellner określał pojęciem egzosocjalizacji1'.

Zagadnienie to rozwijali także inni myśliciele, np. Anthony D. Smith, dla tematu niniejszego artykułu szczególnie istotne są jednak prace przywołanej powyżej trójki.

\footnotetext{
Tamże.

Tamże, s. 53.

10 Tamże, s. 54.

11 Tamże, s. 55.

12 Tamże, s. 146.

14 Tamże, s. 192.

15 Tamże, s. 194-195.

16 Tamże, s. 197.
}

13 Tamże. 
Z jednej strony Treitschke i Renan mieli wpływ na światopogląd Wichita, z drugiej teoria Gellnera wydaje się adekwatna do opisu przypadku Tajlandii.

W kwestii tożsamości narodowej posłużyć się można tezami wspomnianego powyżej Smitha, który uważał ją za wielowymiarowe poczucie przynależności do wspólnoty narodowej, „tożsamość kolektywną”, czerpiącą z innych tożsamości dzielonych przez ludzi (religijnej, etnicznej, klasowej) ${ }^{17}$. Można zatem stwierdzić, że ów świadomy nation building ma za cel wytworzenie właśnie wspólnej „tożsamości narodowej” lub jej modyfikację.

\section{GENEZA PROCESU TWORZENIA NARODU TAJSKIEGO}

Przesłanki do stwierdzenia konieczności budowania wspólnoty narodowej i tego, w jaki sposób ten proces przebiegał, miały w Syjamie dwojaki charakter ${ }^{18}$. Po pierwsze - zewnętrzny, jako że były związane z dynamiczną ekspansją imperiów kolonialnych i chęcią uchronienia się przed podzieleniem losu sułtanatów malajskich, Birmy czy Wietnamu. Po drugie - wewnętrzny, ponieważ był to element przekształcania struktury społecznej i administracyjnej w kraju, następstwo odejścia od zdecentralizowanego modelu mandali do państwa z jednym ośrodkiem władzy, Bangkokiem.

\subsection{Zewnętrzne powody tworzenia narodu tajskiego}

Syjam, podobnie jak inne kraje Azji Wschodniej i Południowo-Wschodniej, u schyłku XIX w. rozpoczął proces recepcji europejskich i amerykańskich technologii, praw i idei. Miał jednak unikalną szansę dokonywać tego jako państwo suwerenne i z własnej inicjatywy, nie stał się bowiem posiadłością kolonialną czy państwem zależnym od któregoś z europejskich mocarstw. Nie znaczy to, że uniknął dyktatu zachodnich potęg - tak jak w wypadku stawianej za wzór skutecznej i szybkiej westernizacji Japonii wymuszono na Królestwie Syjamu szereg traktatów gwarantujących przywileje kupcom z Zachodu.

Francuzi zainteresowanie tym regionem przejawiali już od schyłku XVIII w. Wobec rosnącej pozycji Wielkiej Brytanii na subkontynencie indyjskim to Wietnam został obrany za kluczowy kierunek ekspansji francuskiego mocarstwa kolonialnego ${ }^{19}$. Początkowo, w XVIII w., oba kraje starały się rozwijać swoją pozycję za sprawą misjonarzy i kupców wysyłanych do Indochin (w tym do regionów, które ostatecznie znalazły się w posiadaniu strony przeciwnej), jednak szybko osiągnięto generalny konsensus co do stref wpływów: terytoria na zachód od Syjamu były wyłączną przestrzenią ekspansji brytyjskiej, zaś

17 A. D. Smith, National Identity, Reno 1999, s. 14.

18 Abstrahując od teorii Gellnera - opisana przez niego konieczność wystąpienia nacjonalizmu nie decyduje o tym, jaki ów nacjonalizm będzie miał kształt. Determinowane jest to warunkami lokalnymi, które należy skrupulatnie rozważyć i przeanalizować.

19 N. Tarling, The Establishment of the Colonial Regimes, [w:] Cambridge History of Southeast Asia, vol. 2: The Nineteenth and Twentieth Centuries, red. tenże, Cambridge 1994, s. 41. 
na wschód - francuskiej ${ }^{20}$. Brytyjczykom szczególnie zależało na zabezpieczeniu Indii, do czego w ich mniemaniu konieczna była Birma, Francuzi zaś potrzebowali portów w Azji Wschodniej, musieli bowiem równoważyć wpływy brytyjskie, które stały się nieporównywalnie silniejsze po opanowaniu przez nich Hongkongu. Interwencja franko-hiszpańska w Danang w 1858 r. rozpoczęła okres bezpośrednich wpływów francuskich w Wietnamie ${ }^{21}$. W 1882 r. zajęli oni Hanoi, co wywołało reakcję Chin i stało się przyczyną wojny między oboma krajami. Szybka i skuteczna kampania przeciwko Państwu Środka zmusiła je do podpisania w 1885 r. w Tianjinie traktatu pokojowego, na mocy którego godziło się na utworzenie z terytorium Wietnamu francuskiego protektoratu ${ }^{22}$.

Rychło po zdobyciu przez Francuzów przyczółku w Indochinach król Kambodży zwrócił się do nich z ofertą zawarcia traktatu o przyjaźni, jednocześnie gwarantując im szereg przywilejów. Miało to miejsce już w $1863 \mathrm{r}^{23}$ Wiedza Francji o Kambodży była szczątkowa, dopiero w $1861 \mathrm{r}$. tereny te (oraz część Laosu) zostały po raz pierwszy zbadane i opisane. Zrobił to odkrywca Henri Mouhot, który zresztą dokonał żywota w Luang Prabang w tym samym roku ${ }^{24}$. Między jego wyprawą a oddaniem się króla Norodoma pod francuskie zwierzchnictwo minęły zaledwie dwa lata. Brak rzetelnych informacji na temat kraju, nad którym obejmowała panowanie, nie przeszkadzał Francji. Była to okazja do przejęcia kontroli nad handlem na Mekongu, który już wtedy stanowił obiekt zainteresowania elit paryskich ${ }^{25}$. Khmerzy również byli zadowoleni. Próby uzyskania wsparcia Francuzów podejmowano już w 1853 r., gdy król Duang wysłał swego posła do konsulatu Francji w Singapurze, jednak nie doszło wówczas do porozumienia ${ }^{26}$.

Po 1863 r. wpływy syjamskie w Kambodży nie zostały szybko wyrugowane. Już po zawarciu porozumienia z Paryżem Norodom zwodził Bangkok, twierdząc, że pozostaje wierny królowi Mongkutowi. Koronacja Norodoma była ostatnią, przy której obecni byli przedstawiciele króla Syjamu (dotychczas to właśnie on wydawał zezwolenie na koronację), i pierwszą, w której wzięli udział Francuzi ${ }^{27}$. W 1867 r. Syjam formalnie uznał zwierzchnictwo Francji nad Kambodżą ${ }^{28}$.

Opanowanie Laosu (dzisiejszej Laotańskiej Republiki Ludowo-Demokratycznej) zajęło Francji nieco więcej czasu. Pierwsze roszczenia wobec tych terytoriów (wów-

\footnotetext{
Tamże, s. 41-42.
}

21 Tamże, s. 44.

22 M. Stuart-Fox, A Short History of China and Southeast Asia. Tribute, Trade and Influence, Crows Nest 2003, s. 121.

23 G. Muller, Colonial Cambodia's „Bad Frenchman”. The Rise of French Rule and Life of Thomas Caraman, 1840-87, London-New York 2006, s. 39-40.

24 H. Mouhot, Travels in the Central Parts of Indo-China (Siam), Cambodia, and Laos, during the Years 1858, 1859, and 1860, vol. 2, London 1864, s. 160.

25 G. Muller, Colonial Cambodia's „Bad Frenchman”..., s. 36.

26 D. P. Chandler, History of Cambodia, Boulder 2008, s. 164.

27 Tamże, s. 172-173.

28 P. P. Mishra, The History of Thailand, Santa Barbara 2010, s. 80. 
czas podzielonych na mniejsze królestwa i tereny plemienne pozostające poza władzą zorganizowanego państwa) wysunięto po pokonaniu Cesarstwa Chińskiego w 1885 r. i przejęciu kontroli nad Wietnamem. Twierdzenia, jakoby państwa laotańskie składały trybut Wietnamowi, nie znalazły potwierdzenia w dokumentach ${ }^{29}$. Było to spowodowane faktem, że Laos stanowił sferę wpływów syjamskich. W XVIII w. król Taksin podporządkował sobie terytorium płaskowyżu Korat (Isaan, prawobrzeżny Laos, obecnie północno-wschodnia Tajlandia) i lewobrzeżnego Laosu. Pozycja Bangkoku umocniła się w latach 20., kiedy stłumiono antysyjamskie powstanie Chao Anouvonga. Po brutalnym rozprawieniu się z buntownikami Isaan został włączony do Królestwa Syjamu, a zależność trybutarna pozostałych trzech księstw laotańskich (Luang Prabang, Champassak i Wientian) została potwierdzona. Roszczenia Francji miały w związku z tym bardzo wątpliwe podstawy, jednak przejęcie kontroli nad Mekongiem pozostawało w centrum zainteresowania Paryża. Wicekonsul Indochin Francuskich Auguste Pavie stwierdzit, że Mekong stanowi naturalną granicę, na której Indochiny Francuskie muszą się oprzeć ${ }^{30}$.

Ażeby zrealizować swoje zamierzenia co do opanowania Mekongu, Francuzi postanowili wykorzystać sprawdzoną dyplomacje kanonierek. 13 lipca 1893 r. francuskie okręty pokonały siły syjamskie pod Paknam ${ }^{31}$, fortem chroniącym dostępu do Chao Phrayi, potężnej rzeki, żywicielki Tajlandii, która przepływając przez Bangkok, oddziela przemysłową dzielnicę Thonburi od Rattanakosinu. Okręty dotarły do stolicy i zacumowały w pobliżu francuskiego konsulatu ${ }^{32}$. Bezpośrednio zagrożony został pałac królewski, który znajduje się przy brzegu rzeki w dzielnicy Rattanakosin. Syjamskie elity władzy mogły spodziewać się najgorszego: francuskiego ataku na siedzibę króla, zniszczenia symbolu Syjamu i władzy monarszej w kraju, w przypadku niespełnienia francuskich żądań.

Zakres tych żądań nie był jasny. W tamtym okresie bardzo silna i wpływowa była w Paryżu parti colonial, która domagała się zdecydowanych kroków względem nieskolonizowanych i niepodporządkowanych krajów Azji i Afryki. Lider zwolenników kolonializmu, Théophile Delcassé, głosił tezę, że w relacjach pomiędzy Francją a Zjednoczonym Królestwem konieczna jest równowaga - Brytyjczycy kontrolują Nil, w takim razie Francuzi muszą mieć Mekong ${ }^{33}$. Sam minister spraw zewnętrznych Zjednoczonego Królestwa, lord Rosebery, mimo swej frankofobii nie tylko godził się, ale wręcz publicznie zachęcał Francję do opanowania terenów dolnego i środkowego Mekongu $^{34}$. Pojawiały się jednak głosy bardziej radykalne - wicekonsul Pavie stwier-

\footnotetext{
29 G. Evans, The Short History of Laos. The Land in Between, Crows Nest 2002, s. 40.

30 Tamże.

31 D. Meyers, Siam under Siege (1893-1902). Modern Thailand's Decisive Decade, from the "Paknam Incident" to the First Flowering of the "Chakri Reformation", "Journal of the Siam Society" 1994, vol. 82, pt. 2, s. 121.

32 Tamże, s. 122.

33 Tamże, s. 124.

34 Tamże, s. 123.
} 
dził, że jeżeli Syjam będzie stawiał opór w opanowaniu Mekongu, to protektorat nad Tajlandia będzie nasza rekompensatą ${ }^{35}$. Tak się jednak nie stało. Na mocy zawartego porozumienia Syjam zrezygnował ze swych praw do lewobrzeżnego Laosu, zgodził się też na dwudziestopięciokilometrową strefę zdemilitaryzowaną na prawym brzegu Mekongu, francuską okupację portu Chanthaburi (jeden z głównych portów nad Zatoką Tajską, we wschodniej Tajlandii) ${ }^{36}$, a także zapłacenie reparacji w wysokości 3 mln franków ${ }^{37}$.

Od 1896 r. między Francją i Zjednoczonym Królestwem panował konsensus w kwestii statusu Syjamu jako kraju buforowego ${ }^{38}$, który miał oddzielać posiadłości kolonialne obu mocarstw. Miało to zapobiec niepożądanym starciom granicznym, których eskalacja mogłaby doprowadzić do poważnego konfliktu. Było to rozwiązanie analogiczne do tego, które Brytyjczycy zastosowali w Wielkiej Grze o Azję Centralną z Rosją. Przebieg linii Duranda, utworzenie na terytorium Afganistanu Korytarza Wachańskiego, wreszcie podział stref wpływów w Persji (wraz z neutralną strefą buforową) - wszystko to było elementem konsensualnego dzielenia się światem przez mocarstwa i traktowania państw azjatyckich jako łupu. Niekontrolowane bezpośrednio przez żadne z potęg europejskich kraje miały być jedynie buforem, gdyż ich bogactwa były mniej cenne niż zachowanie pokoju.

Jednak nie wszyscy podzielali opinię o konieczności istnienia stref buforowych. Generalny Gubernator Indochin Francuskich, Paul Doumer, rozesłał do kolonialnych oficjeli w 1899 r. telegram o następującej treści: Musimy upewnić się, że Syjam, nad którym od kilku lat zwiększa się brytyjsk a dominacja, zwrócit się ku Francji i mocniej związat się z Indochinami. Protegowan ${ }^{39}$, strefy neutralne etc. - wszystko to pozostaje samo dla siebie bez znaczenia. Istota tych kwestii jest ich rola oręża politycznego. Musimy doprowadzić do okupacji Battambangu i, przede wszystkim, Khoratu. Z czasem oznaczatoby to rozpostarcie przez nas protektoratu nad catym Syjamem ${ }^{40}$.

Ostatecznie Syjam uniknął losu przytłaczającej większości krajów Azji Południowo-Wschodniej i pozostał suwerenny. Roszczenia co do Koratu nie przerodzily się w faktyczną kontrolę francuską nad terenami równiny Korat, aczkolwiek na mapach z przełomu wieków ziemie te bywają oznaczone jako Zone d'Influence Française ${ }^{41}$.

G. Evans, The Short History of Laos..., s. 40.

36 H. E. Smith, G. S. Nieminen, M. K. Win, Historical Dictionary of Thailand, Lanham 2005, s. 115.

37 D. na Pombejra, Siam and the West, Kingdom of, [w:] Encyclopedia of Western Colonialism since 1450, red. T. Benjamin, Detroit 2007, s. 1019.

38 Tamże.

39 Mowa tu o osadnikach laotańskich, którzy byli zachęcani przez Francję do osiedlania się na terenie Isaanu. Mieli oni stanowić pretekst do ewentualnej interwencji zbrojnej w Syjamie. Proces osadnictwa lewobrzeżnych Laotańczyków po drugiej stronie Mekongu rozpoczął się jeszcze przed panowaniem francuskim, w pierwszej połowie XIX w. Por. G. Evans, The Short History..., s. 30-31.

40 P. Tuck, The French Wolf and the Siamese Lamb. The French Threat to Siamese Independence, 1858-1907, Bangkok 1995, s. 195.

41 Zob. D. Meyers, Siam under Siege..., s. 120. 
Relacje między oboma państwami rozwijały się dość dynamicznie. W 1904 r. podpisano traktat, na mocy którego Francja uzyskała prawo do rozwoju infrastruktury w Isaanie, a także przejęła zwierzchnictwo nad laotańskim księstwem Luang Prabang. Potwierdzono przebieg granicy na Mekongu, zlikwidowano strefę zdemilitaryzowaną, Chanthaburi zwrócono Syjamowi, a kwestię francuskich protegowanych rozstrzygnięto ${ }^{42}$. Ambasador USA w Bangkoku, Hamilton King, nazwał ów dokument wielkim postępem dla Syjamu i wskazał, że rozejm jest okazją, aby kraj udowodnit, że może sam sobą rządzic ${ }^{43}$.

Delimitacja granic rozpoczęła się od traktatu z Francją z 1904 r., ale nie była to ostatnia taka umowa, którą Bangkok podpisał w kolejnej dekadzie. Już trzy lata później promulgowano porozumienie, w ramach którego Kambodża odzyskała prowincje Battambang, Siem Reap i Sisophon ${ }^{44}$, a w 1909 r. Brytyjczycy przejęli kontrolę nad dotychczas zależnymi od Syjamu malajskimi sułtanatami Perlis, Kedah, Kelantan i Terengganu ${ }^{45}$.

Syjam przez długie dekady pozostawał centralnym punktem zainteresowania europejskich mocarstw. Jak zauważył King, wraz z początkiem XX w. nadarzyła się okazja, by kraj ten wybił się na podmiotowość i przestał być tylko przedmiotem sporu między Wielką Brytanią a Francją albo - jak to sformułował Doumer - buforem, czyli orężem politycznym.

Proces delimitacji granic w zasadzie zakończył się w 1909 r., jednak pozycja Syjamu nie była taka pewna - kraj, ze wszystkich stron otoczony posiadłościami kolonialnymi, był osamotniony jako niezależny ośrodek władzy w regionie. Strach przed podporządkowaniem któremuś z europejskich mocarstw był jedną z sił napędowych kreowania tożsamości tajskiej. Metodą zmniejszania ryzyka podbicia było wdrażanie programów reform. W kwestii budowania narodu i kształtowania tytułowej „tajskości” najważniejsze stały się reformy administracyjne.

\subsection{Wewnętrzne powody tworzenia narodu tajskiego}

Budowanie narodu przez instytucje było pierwszym krokiem podjętym w Tajlandii (najpewniej bez świadomości wkładu w proces kształtowania społeczności). W zasadzie od momentu zaistnienia zagrożenia ze strony Francji i Zjednoczonego Królestwa władcy Tajlandii starali się zreformować skostniałą, działającą na tradycyjnych zasadach administrację.

Kraje Azji Południowo-Wschodniej, szczególnie z kręgu buddyzmu therawada, funkcjonowały w ramach systemu mandali (nazywanego również systemem solarnym

42 Traktat syjamsko-francuski w sprawie delimitacji granicy między francuskimi i syjamskimi terytoriami oraz ustanowienia systemu jurysdykcyjnego z dnia 13 lutego $1904 \mathrm{r}$.

43 Departament Stanu USA, Papers relating to the foreign relations of the United States, with the annual message of the president transmitted to Congress December 5, 1905, Washington 1905, s. 834-835.

44 L. P. Briggs, The Treaty of March 23, 1907 Between France and Siam and the Return of Battambang and Angkor to Cambodia, „The Far Eastern Quarterly” 1946, vol. 5, nr 4, s. 439-454, [online] https:// dx.doi.org/10.2307/2049791.

45 Traktat syjamsko-brytyjski podpisany w Bangkoku dnia 10 marca 1909 r. 
lub galaktycznym). W centralnym miejscu znajdował się władca, następnie obszary i ludzie bezpośrednio zależni od niego. Im dalej od władcy - szczególnie dosłownie, pod względem odległości fizycznej - tym jego sita ciążenia jest mniejsza, a zależność słabsza. Autorytet jest zależny od realnej możliwości oddziaływania, więc niedostępne rubieże w najlepszym wypadku będą rządzone przez dziedzicznych trybutariuszy, zaś niedaleka prowincja będzie regularnie płacić podatki i respektować prawa ustanawiane przez władcę ${ }^{46}$.

Victor Lieberman stworzył matrycę ustrojów administracyjnych krajów Azji Południowo-Wschodniej. Jest to spektrum systemów solarnych, w których największą rolę odgrywa sita ciążenia władcy, a zatem stopień centralizacji państwa. Syjam został przez niego postawiony po stronie krajów bardziej scentralizowanych (mowa o okresie od XVIII w. do 1840 r. $)^{47}$, co może budzić pewne wątpliwości. Faktycznie władza Bangkoku była silna w Tajlandii Centralnej, Tajlandii Wschodniej, a także części Tajlandii Południowej (chociaż w tym wypadku należałoby wykluczyć nie tylko kraje lenne, takie jak malajskie sułtanaty, lecz także miasta położone bliżej Bangkoku, takie jak Ranong). Tajlandia Północna, czyli Lanna, była niezależna nie tylko de facto, ale również de iure - tamtejsze królestwa zostały zmuszone przez króla Taksina do uznania jego zwierzchności w XVIII w., formalne do ich inkorporacji do Królestwa Syjamu doszło w 1892 r., ale dopiero w latach 30. XX w. zmarli ostatni królowie, którzy jeszcze po aneksji władali Tajlandią Północną ${ }^{48}$. Silna odrębność tego regionu była też zauważalna dekady później, gdy lokalne elity odmówiły implementacji Ustawy o kontroli kosztów dzierżawy z 1950 r., powołując się na odwieczne prawa Lanny i własne regulacje dotyczące wysokości renty ziemskiej ${ }^{49}$.

Odrębność administracyjna Isaanu była jeszcze bardziej wyraźna. Jak już wspomniano, tereny te po raz pierwszy zostały opanowane przez Bangkok w okresie panowania króla Taksina w XVIII w. Podporządkował on sobie obszar od Nakhon Ratchasimy aż po dzisiejszy Laos; ziemie te (z wyjątkiem Nakhon Ratchasimy) były od tego momentu lennem syjamskim. Jak już wspomniano, prawobrzeżny Laos formalnie wcielono do Królestwa Syjamu po nieudanym powstaniu Chao Anouvonga. Słowo „formalnie” jest kluczowe: de facto Isaan pozostawał poza kontrolą Bangkoku aż do schyłku XIX w., a w przypadku niektórych obszarów nawet na początku XX w.

Proces stopniowej centralizacji Syjamu w okresie panowania króla Chulalongkorna (1868-1910) i przejmowania faktycznej kontroli nad północno-wschodnimi rubieżami państwa dokładnie opisał Michael Vickery. Wymienił miasta, w których od czasów króla Taksina aż do przełomu wieków u władzy pozostawały lokalne rody książęce - władza Bangkoku nad nimi była iluzoryczna. Biurokraci ze stolicy zaczęli zarządzać w Surinie

46 Por. V. Lieberman, Strange Parallels. Southeast Asia in Global Context, c. 800-1830, vol. 1: Integration on the Mainland, Cambridge 2003, s. 31-33.

47 Tamże, s. 35.

48 H. Penth, A Brief History of Lanna. Northern Thailand from Past to Present, Chiang Mai 2004, s. 3.

49 T. Haberkorn, Revolution Interrupted. Farmers, Students, Law, and Violence in Northern Thailand, Madison 2011, s. 32, 44 . 
w 1907 r. (wcześniej prowincją władał książę z plemienia Suoy), w Nakhon Phanom w 1902 r., a w Ubonie w 1886 r. (to miejscowość przygraniczna o szczególnym znaczeniu dla obronności państwa, więc została uznana za priorytet $)^{50}$. Jak widać, proces zastępowania lokalnych struktur władzy administracją państwową trwał kilkadziesiąt lat.

Drugim aspektem w sferze wewnętrznej przesłanek budowania wspólnoty narodowej jest wysoki stopień heterogeniczności etnolingwistycznej Syjamu. Po zetknięciu się z zachodnią koncepcją narodu jako grupy o wspólnym języku, kulturze, historii, gospodarce i strukturze politycznej nastąpiła prosta konstatacja - poddani króla Syjamu należą do bardzo wielu grup, które nie mają wspólnych mianowników takich jak język, kultura czy nawet historia. Północ i północny wschód niedawno zostały wcielone, ludzie tam mieszkający są Lanna, używają innego języka i innego pisma, a nawet jedzą inny ryż (charakterystyczny ryż kleisty). Co więcej, część z nich nawet nie jest Lanna, a należy do jednego z dziesiątków plemion (Akha, Hmong, Yao czy Lahu) i nie dość, że mówi kompletnie niezrozumiałym językiem (lanna i centralny tajski należą do rodziny języków tai-kadai, część języków plemiennych - do innych rodzin językowych), to nie wyznaje buddyzmu therawada i żyje w społecznościach plemiennych.

Analogiczna sytuacja wystąpiła w Isaanie. Był on zamieszkany przez Laotańczyków, lud o zbliżonej kulturze i języku. Różnice występowały także w sferze religii. Co prawda Isaańczycy też są buddystami therawada, ale mają odmienną tradycję (to tam powstała Tradycja Leśna). I znowu, tak jak w przypadku Lanny, mniejszym problemem była dominująca grupa ludności, podobnie jak Syjamczycy porozumiewająca się językiem z rodziny tai-kadai. Sprawę znacznie komplikowały mniejszości i lokalne plemiona, jeszcze bardziej odmienne niż w Lannie. Region zamieszkiwany jest bowiem przez ludy Monów i Khmerów, a także szereg mniejszych plemion laotańskich.

Heterogeniczność północy i północnego wschodu nadal pozostaje faktem. O odmienności mieszkańców tamtych terenów i żywotności lokalnego języka napisano wiele opracowań ${ }^{51}$. Tym większym było to wyzwaniem dla tworzącego się nowoczesnego państwa syjamskiego. Jak już wspomniano, proces formowania struktur administracyjnych trwał wiele dekad, co było związane z silną autonomicznością lokalnych struktur władzy, wzmacniającą odrębność etnolingwistyczną Isaanu i Lanny. Owa odrębność była podnoszona jeszcze po II wojnie światowej jako argument przeciwko implementacji pewnych norm prawnych - sprzecznych z wielowiekowa tradycja i nieprzystajacych do tradycyjnego charakteru spotecznosici ${ }^{52}$.

50 M. Vickery, Thai Regional Elites and the Reforms of King Chulalongkorn, „The Journal of Asian Studies" 1970, vol. 29, nr 4, s. 863-864, [online] https://dx.doi.org/10.2307/2943093.

51 Zob. J. Draper, Introducing Multilingual Thai-Isan-English Signage in a Thai University, „Journal of Lao Studies" 2013, vol. 4, nr 1; J. Herington [i in.], Sociolinguistic Survey of Northern Thai, SIL International, Electronic Survey Report 2013-009, Dallas 2013; S. Phattharathanit, Identity Maintenance in Lanna (Northern Thai), "Journal of the Southeast Asian Linguistics Society” 2012, vol. 5; D. McCargo, K. Hongladarom, Contesting Isan-ness: Discourses of Politics and Identity in Northeast Thailand, „Asian Ethnicity” 2004, vol. 5, nr 2, s. 219-234, [online] https://dx.doi.org/10. 1080/1463136042000221898.

52 T. Haberkorn, Revolution Interrupted..., s. 32. 
Schyłkowy okres syjamskiego absolutyzmu to zatem czas powolnej budowy nowoczesnego aparatu biurokratycznego i stopniowej centralizacji państwa. Fundamentem tych zmian był autorytet królewski i bezpośrednie relacje władcy z wasalami i poddanymi. Król stanowil jedyny punkt zaczepienia między mającymi ze sobą niewiele wspólnego grupami, które zamieszkiwały obszar oznaczany na mapach jako „Królestwo Syjamu”.

\section{KONCEPCJA NARODU TAJSKIEGO WICHITA WATHAKANA}

\subsection{Rojalistyczna koncepcja narodu Vajiravudha}

Pierwsze próby stworzenia koncepcji narodu tajskiego należy wiązać z postacią króla Vajiravudha (1910-1925), następcy wielkiego reformatora Chulalongkorna. Vajiravudh skonstruował pojęcie chat Thai (naród tajski), który dzieli wspólną historię, sztukę, jezzy, literaturę, buddyzm, mitość do osoby króla, a przede wszystkim oddanie wolności [tai] zawarte w wojowniczym duchu, który król często nazywat duchem Dzikich Tygrysów $w^{53}$.

Chat Vajiravudha posiadał trzy spoiwa - wspólną historię królestw Sukhothai, Ayutthai i Rattanakosin, monarchę jako głowę państwa i buddyzm therawada jako religię dominującą ${ }^{54}$. W sposób oczywisty była to próba tworzenia nacjonalizmu czysto syjamskiego - głównie przez odwołanie się wyłącznie do historii trzech państw protosyjamskich. Ekskluzywizm tej koncepcji mógł antagonizować pomijanych poddanych w Królestwie Tajlandii, których było więcej niż Syjamczyków (Laotańczyków, Khmerów, Malajów, członków plemion). Istotą „tajskości” w tym wydaniu była jednak postać króla.

Pojęcie zostało rozwinięte przez księcia patriarchę Wachirayanwarorota, który wzmocnił aspekt buddyjski (m.in. przez promocję edukacji monastycznej), oraz przez księcia Damronga Rajanubhapa, dla którego najistotniejsze były koncyliacyjność i niekonfrontacyjna natura Tajów; jego zdaniem dzięki nim władcy syjamscy mogli rządzić zróżnicowanym etnicznie państwem ${ }^{55}$.

Koncepcja rojalistyczna spotkała się jednak z podwójnym problemem - wyczerpaniem się modelu absolutystycznego w Syjamie oraz słabością instytucji króla. Wykształcone na Zachodzie elity dążyły do szybkiej zmiany, której następca Vajiravudha, powszechnie uważany za słabego władcę Prajadhipok (1925-1935), nie był gwarantem. Władca o słabym autorytecie przyniósł kres koncepcji narodu wysuwanej przez Pałac.

53 A. W. Jelonek, Wielokulturowość, separatyzm i budowa państwa narodowego w Tajlandii, Kraków 2011, s. 138.

54 M. J. Meyer, The Idea of the Social in the Thought of Three Thai Politicians and Intellectuals in the mid-20th Century, "Journal of Humanities and Social Sciences” 2010, nr 2, s. 8-9.

55 S. Sattayanurak, The Construction of Mainstream Thought on "Thainess" and the "Truth" Constructed by „Thainess”, dysertacja doktorska, Department of History, Faculty of Humanities, Chiang Mai University, Chiang Mai 2008, s. 6-8, [online] http://www.fringer.org/wp-content/writings/thainess-eng.pdf. 


\subsection{Rewolucja Syjamska 1932 r.}

Swoistym przewrotem kopernikańskim w procesie modernizacji kraju oraz w konstruowaniu pojęcia narodu tajskiego była Rewolucja Syjamska z 1932 r. Jej charakter najlepiej oddaje termin rewolucja biurokratyczna, czy może raczej rewolucja biurokratów. Jak pisał Erik Kuhonta, fundamentalnym problemem [...] byta rosnaca frustracja coraz lepiej wyksztatconych urzędników cywilnych i wojskowych ${ }^{56}$. Wśród owych sfrustrowanych biurokratów, wykształconych na Zachodzie intelektualistów, na czoło wysunęła się siedmioosobowa grupa spiskowców, która 5 lutego 1927 r. w Paryżu zawiązała Khana Ratsadon (Partię Ludową) ${ }^{57}$. Adam W. Jelonek nazywał ich promotorami, wskazując, że faktyczna Partia Ludowa powstała później ${ }^{58}$. Sformułowali oni program opierający się na sześciu zasadach:

1. Wolności i równości w polityce, biznesie i wobec prawa.

2. Wewnętrznego pokoju i porządku.

3. Planowania gospodarczego ukierunkowanego na zapewnienie wszystkim pracy idobrobytu.

4. Równych przywilejów.

5. Wolności obywatelskiej i osobistej.

6. Powszechnej edukacji ${ }^{59}$.

Przywódcą intelektualnym grupy był Pridi Banomyong. Nasiąknął on w trakcie studiów w Paryżu ideami rządów prawa i aktywnego udziału państwa w życiu gospodarczym. Drugi postulat miał zostać zrealizowany w zgodzie z powyższymi zasadami, pierwszy natomiast wymagał wystąpienia przeciwko władzy monarszej - tylko obalając absolutyzm, można było zaprowadzić rządy prawa, w których nawet król musi respektować ustawy i podporządkować się im ${ }^{60}$.

Po powrocie do kraju grupie udało się zdobyć poparcie wielu wpływowych wojskowych i urzędników. Atmosfera w Syjamie sprzyjała nastrojom rewolucyjnym - rozwijała się działalność grup komunistycznych, pojawiały się postulaty republikańskie, a ze środowisk dworskich wychodziły propozycje wzmocnienia władzy monarszej na wzór rozwiązań stosowanych przez Benito Mussoliniego we Włoszech ${ }^{61}$. Ostatecznie to Khana Ratsadon przejęło inicjatywę i 24 czerwca 1932 r. przeprowadziła zamach stanu, pozostawiając króla na tronie, jednak pozbawiając członków rodziny królewskiej większości istotnych stanowisk państwowych. Po trzech dniach proklamowano pierwszą w histo-

56 E. M. Kuhonta, The Institutional Imperative. The Politics of Equitable Development in Southeast Asia, Stanford 2011, s. 134.

57 Zob. S. Barmé, Luang Wichit Wathakan and the Creation of Thai Identity, Singapore 1993, s. 64; M. Peleggi, Thailand. The Worldly Kingdom, London 2007, s. 121; C. Baker, P. Phongpaichit, A History of Thailand, Cambridge 2014, s. 115.

58 A. W. Jelonek, Wielokulturowość, separatyzm..., s. 150.

59 E. Kuhonta, The Institutional Imperative..., s. 135.

60 C. Baker, P. Phongpaichit, A History of Thailand..., s. 115.

61 Tamże, s. 117. 
rii Syjamu konstytucję $e^{62}$. Na czele nowego rządu stanął rojalista, Phraya Manopakon. Zgoda na objęcie przez niego funkcji prezesa rady ministrów była próbą załagodzenia sytuacji przez puczystów. Na niewiele się to zdało - król nazwał projekt reform gospodarczych Pridiego komunistycznym, a jego samego przyrównał do Stalina. Przywódca Khana Ratsadon został zmuszony do opuszczenia kraju, a jego zwolennicy wyrugowani z ważnych stanowisk państwowych. Doprowadziło to do kolejnego przewrotu w czerwcu 1933 r., w którym władzy został pozbawiony Manopakon, a Pridi powrócił z wygnania ${ }^{63}$. Nowym premierem został Phraya Phahonphonhayuhasena (Phahon).

W październiku doszło do kolejnej próby przywrócenia władzy Pałacu, czyli Rewolty Księcia Boworadeta, byłego ministra wojny. Została jednak szybko stłumiona. W kolejnych dwóch latach doszło jeszcze do dwóch buntów rojalistycznych, ale żaden z nich się nie powiódł. W marcu 1935 r. pozostający na wygnaniu król Prajadhipok abdykował, a nowym władcą został dziesięcioletni Mahidol, który przez kolejnych 16 lat pobierał nauki w Europie ${ }^{64}$. Khana Ratsadon przejęła pełną, nieskrępowaną autorytetem monarszym władzę w Syjamie.

Jeszcze w 1933 r., w odpowiedzi na starania rojalistów o założenie partii politycznej (na czele tej grupy miał według Ptaita Pabana Mishry stać Wichit ${ }^{65}$ ), Prajadhipok dekretem zakazał funkcjonowanie partii na terenie Królestwa Syjamu, włączając w to Khana Ratsadon ${ }^{66}$. Była to próba osłabienia zwolenników Pridiego i Phibuna, którzy jednak sami dążyli do uniemożliwienia założenia konkurencyjnej Khana Chat (Partii Nacjonalistycznej) ${ }^{67}$. Władca uniemożliwił swoim poplecznikom zawiązanie ugrupowania, jednocześnie uniemożliwiając funkcjonowanie partii reformatorskiej. Nie przyniosło to oczekiwanego skutku; co prawda uniemożliwiło Khana Ratsadon zostanie partią masową, na co liczył Pridi ${ }^{68}$, ale nie osłabiło jej na tyle, by straciła władzę - pomimo tarć frakcyjnych (szczególnie między frakcją wojskową Phibuna i cywilną Pridiego) większość sporów personalnych i programowych udawało się rozwiązać koncyliacyjnie. Khana Ratsadon utrzymała jedność aż do $1941 \mathrm{r}$.

Co więcej, pomysł zakazu funkcjonowania partii politycznych został przez reformatorów zaadaptowany. Po stłumieniu Rewolty Księcia Borowadeta przyjęli oni w 1934 r. Ustawę o kontroli prasy oraz podtrzymali zakaz działalności ugrupowań politycznych. Otwarcie przyznano, że celem legislacji było przeciwdziałanie tendencjom reakcyjnym ${ }^{69}$. Ustawa ta dołączyła do uchwalonej rok wcześniej Ustawy antykomunistycznej ${ }^{70}$ jako jedno z ważniejszych ograniczeń wolności obywatelskich, których respektowanie było po-

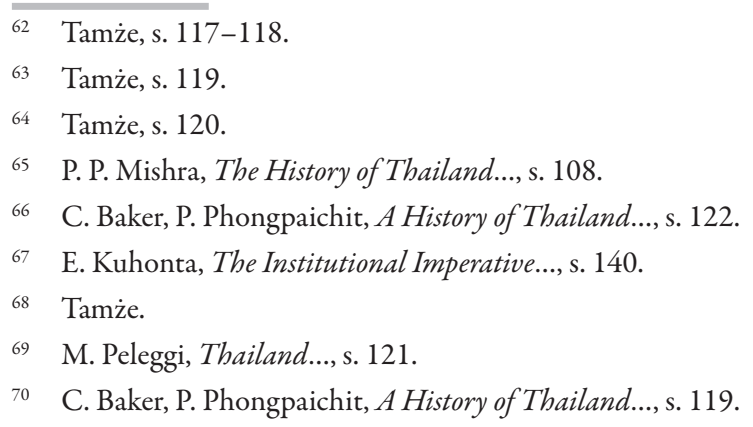


stulatem założycieli Khana Ratsadon. Władza starała się w ten sposób zapobiec zarówno ewentualnej rewolucji komunistycznej, jak również rojalistycznej kontrrewolucji. Bezpośrednim skutkiem było utrwalenie systemu de facto monopartyjnego, który przetrwał w Tajlandii ponad 10 lat.

Przed delegalizacją partii politycznych Khana Ratsadon udało się zwerbować setki tysięcy członków i utworzyć lokalne struktury. Kolportowano też prasę partyjną (szczególnie aktywne było socjalistyczne skrzydło ugrupowania, które opublikowało m.in. tłumaczenie pamfletu brytyjskiego socjalisty Johna W. Kneeshawa What Socialism Means? $)^{71}$. Jednak wprowadzenie zakazu funkcjonowania partii politycznych odwróciło proces aktywizacji obywatelskiej społeczeństwa - struktury Khana Ratsadon uległy rozwiązaniu, a partia pozostała nieformalnym stowarzyszeniem elit rządzących. Sytuacja ta odbiegała od zamysłu Pridiego, który chciał stworzyć inkluzyjną organizację masową na wzór chińskiego Guomindangu. Nie posiadając oparcia w strukturach partyjnych, Khana Ratsadon skupiła się na zdobyciu wsparcia starych elit i budowaniu wspólnoty w oparciu o nacjonalistyczne postulaty Wichita.

\subsection{Ideologia Wichita Wathakana}

\subsubsection{Wykształcenie i wczesne inspiracje}

Rodzina Luanga Wichita Wathakana pochodziła z Chin, jednak on i jego rodzeństwo zostali wychowani na Tajów. W młodości Wichit odbył nauki w świątyni buddyjskiej, później studiował w Paryżu. Jego pierwsze publikacje traktowały o buddyzmie i jodze i były wzbogacone o rozważania psychologiczne oparte na wiedzy zdobytej we Francji. Pisał też o wybitnych postaciach w tajskiej historii, a także prowadził audycję radiową, w której przekazywał słuchaczom swoje opinie na temat roli kobiety. Najważniejszym dziełem Wichita w okresie przed Rewolucją Syjamską 1932 r. była dwunastotomowa Historia powszechna, która przyczyniła się do uznania go za jednego z najwybitniejszych historyków Syjamu pierwszej połowy XX w. ${ }^{72}$

Na ukształtowanie poglądów Wichita dotyczących pojęcia tajskości wielki wpływ miała książka amerykańskiego misjonarza prezbiteriańskiego Williama C. Dodda, zatytułowana The Tai Race, Elder Brother of the Chinese ${ }^{73}$. Praca Dodda stanowita pierwsze źródło wiedzy na temat ludów Tai-Kadai i obecnie jest krytykowana za ubogi materiał źródłowy (w całości bazowała na chińskich kronikach), wiele nieścisłości i przede wszystkim niepopartą żadnymi dowodami tytułową tezę $e^{74}$. Syjamską adaptacją dzieła Dodda była książka Lak Thai (Pochodzenie Tajów) Khuna Wichitmatry. Wichitmatra rozwinął tezę Dodda, wskazując, że pierwotnym siedliskiem Tajów musiały być góry

\footnotetext{
E. Kuhonta, The Institutional Imperative..., s. 141.

S. Barmé, Luang Wichit..., s. 40-46.

73 Tamże, s. 60, 149.

74 Zob. J. Schliesinger, Tai Groups of Thailand, vol. 1: Introduction and Overview, Bangkok 2001, s. $20-21$.
} 
Ałtaj, a w dołączonej do dzieła mapie oznaczył „utracone terytoria” Syjamu - całe francuskie terytoria Kambodży i Laosu ${ }^{75}$.

Niebagatelne znaczenie miała też twórczość francuskiego historyka i orientalisty René Grousseta i jego postulat uważnego analizowania dziejów w kontekście uwarunkowań geograficznych i środowiskowych. W opinii Wichita warunki skrajne, w jakich funkcjonują niektóre ludy (mrozy strefy podbiegunowej u Eskimosów i malaryczny skwar dżungli równikowej u czarnoskórych Afrykanów), uniemożliwiał im postęp, wobec tego nie stanowią one interesującego i wartościowego przedmiotu badań dla historyka. Warte uwagi były ludy ras mongoloidalnej i białej ${ }^{76}$.

W tym, jak Wichit postrzegał historię, odnaleźć można silne wpływy XIX-wiecznych historiografów. Przebija się wizja historii według Leopolda von Ranke, ukazanie jej wie es eigentlich gewesen (taka, jaka naprawdę byta), aby odkryć istotę rozwoju i mieć wgląd $w$ ludzkie sprawy ${ }^{77}$. Wichit uważal, iż historia jest narzędziem w rękach historyka. Kluczowe miało być zrozumienie innych narodów, gdyż arayachon (ludy cywilizowane) nie mogą żyć w odosobnieniu i interakcje między nimi są koniecznością. Poznanie ich charakteru (nisai) ma służyć poprawie stosunków i vice versa - ukazanie nisai Tajów pozwoli cudzoziemcom lepiej zrozumieć mieszkańców Królestwa Syjamu. Sam proces badawczy musi odbywać się w formie komparatystycznej; w wykonaniu Wichita była to perspektywa bardzo szeroka, gdyż porównywał swój kraj do państw europejskich - Austrii, Bułgarii czy Grecji, które wedle Ligi Narodów przedstawiały niższy poziom rozwoju cywilizacyjnego niż Syjam ${ }^{78}$.

To dążenie do zaprezentowania swojej kultury i uczynienia z niej atutu jest też obecne dzisiaj. Wspomniana we wstępie kampania Discover Thainess w zasadzie powtarza tezy przedstawiane przez Wichita dotyczące nisai Tajów.

\subsubsection{Koncepcja cywilizacji}

Postęp i rozwój w opinii Wichita nie opierał się li tylko na wzroście dobrobytu. W jego koncepcji cywilizacji poziom zaawansowania technicznego i technologicznego, a także akumulacja dóbr materialnych są mniej istotne niż usposobienie ludzi. Naród cywilizowany powinien składać się z khon di (przyzwoitych ludzi). Wbrew intuicji, która mogłaby kojarzyć słowo „postęp” z liberalną wizją szerokich wolności osobistych i partycypacji społecznej, Wichit rozumiał je wprost przeciwnie. Społeczeństwo progresywne miało być strukturą silnie hierarchiczną, kierowaną przez autorytarną władzę, wobec której miało pozostawać wierne i pasywne ${ }^{79}$. Było to spowodowane brakiem wiary w możliwości syjamskiego społeczeństwa - miało ono być zbyt leniwe, by uczestniczyć w jego humanistycznej rewolucji. Jedynie lud dobrze wykształcony mógł

\footnotetext{
75 C. Baker, P. Phongpaichit, A History of Thailand..., s. 112

76 S. Barmé, Luang Wichit..., s. 48-49.

77 P. Lawrence, Nacjonalizm. Historia..., s. 34-35.

78 S. Barmé, Luang Wichit..., s. 49-51.

79 Tamże, s. 51-53.
} 
w opinii Wichita funkcjonować w warunkach demokratycznych ${ }^{80}$. Zostało to zresztą uregulowane prawnie - wybory powszechne całego składu parlamentu miały zostać wprowadzone dopiero wtedy, gdy połowa mieszkańców ukończy cztery klasy szkoły powszechnej lub po 10 latach od uchwalenia konstytucji ${ }^{81}$. Co ciekawe, swoje pesymistyczne przemyślenia dotyczące demokracji Wichit podpierał Arystotelesem i jego twierdzeniem, iż niektórzy rodzą się z predyspozycjami do rządzenia, a inni - do bycia rządzonymi ${ }^{82}$.

\subsubsection{Tożsamość tajska}

Wichit nie zrezygnował z odniesień do historycznych form organizacji Syjamczyków, jednak podszedł do tego zagadnienia w sposób diametralnie odmienny niż Vajiravudh. W koncepcji monarchy najważniejszym czynnikiem, punktem odniesienia dla współczesnego Syjamu, miała być forma rządów antycznych królestw - despotyzm monarszy oparty na tradycji i religii. Dla Wichita co innego było ważne; podkreślał umiłowanie wolności Tajów, ich wielkie osiągnięcia literackie, kulturalne i artystyczne okresu Sukhothai, po którym miał nadejść regres w okresie Ayutthai, związany z przejęciem od Khmerów gospodarki opartej na pracy niewolniczej i koncepcji dewaradży ${ }^{83}$. W przeciwieństwie do Vajiravudha nie stawiał znaku równości między wszystkimi dawnymi państwami tajskimi, zauważał między nimi różnice; tylko to, co dobre, miało być przyjęte jako element tajskiej tożsamości.

Określenie „tajska tożsamość” nie jest w tym miejscu przypadkowe. Wichit skonstruował koncepcję narodu znacznie bardziej inkluzyjnie niż Vajiravudh. Tworzenie narodu było dla niego naturalnym dążeniem rasy i formą organizacji ${ }^{84}$. W wypadku regionu Azji Południowo-Wschodniej głównym aktorem miał być, tak jak według Vajiravudha, Syjam. Jednak inkluzyjna natura koncepcji Wichita nawoływała do stworzenia narodu na poziomie ponadsyjamskim. Syjamczycy mieli przewodzić zjednoczeniu ludów tajskich, do których zaliczano nie tylko te należące do rodziny ludów Tai-Kadai (Laotańczyków, Dambro, Szanów, Isaańczyków, Lanna i innych), lecz także Khmerów, Monów czy Wietnamczyków. Należało dokonać swoistej „kodyfikacji kultury" i reformy języka (jakoby zagrożonego zapożyczeniami z angielskiego i khmerskiego $^{85}$ ), które uzupełniłyby starania administracyjnego zjednoczenia państwa. Realizacja części z tych zadań przypadła Wichitowi, jako urzędnikowi państwowemu (w latach 1934-1942 był szefem Departamentu Sztuk Pięknych ${ }^{86}$, a więc sprawował tę funkcję zarówno w czasach rządów Phahona, jak i Phibuna) i płodnemu pisarzowi.

\footnotetext{
80 C. Baker, P. Phongpaichit, A History of Thailand..., s. 128. 
Wichit był autorem wielu dramatów, wśród których najważniejsze to Luat Suphan (Krew Suphanburi) i Suk Thalang (Bitwa o Thalang). W obu głównymi bohaterami są kobiety stawiające opór birmańskiemu najazdowi. Inne jego dzieła były poświęcone także postaciom historycznym, takim jak król Naseruan i król Taksin ${ }^{87}$; zasadniczo opowiadały one historie wojen obronnych i były sposobem na upowszechnienie ideologii nacjonalistycznej Wichita.

Syjamczycy w wizji Wichita byli mocno wyidealizowani - charakteryzowali się drobiazgowością, umiłowaniem piękna, byli zarazem ludem twórczym i zdolnym w prowadzeniu wojen ${ }^{88}$. Dzięki swym umiejętnościom wojennym stali się potęgą w regionie, jak Ateny byty sercem Grecji, i dlatego inne rasy osiedlity się w granicach Syjamu ${ }^{89}$. W dramacie Ratchamanu jeden z dowódców wojskowych mówi: [Khmerzy są] Tajami jak i my, a także wszyscy na Ztotym Pótwyspie jesteśmy tacy sami [...], a syjamscy Tajowie sa starszymi braćmi ${ }^{90}$. Nie sposób nie zauważyć tu wpływów Dodda i Wichitmatry, wskazujących na „starszeństwo” Syjamczyków wśród ludów Azji Wschodniej. W Chaoying Sanevi (Księzniczka Chaoying) Wichit opisał natomiast braterstwo między Syjamczykami a Szanami, zaś w Mahadevi historię XVI-wiecznej królowej z rejonu Lanna, która dąży do połączenia jej kraju z Syjamem ${ }^{91}$.

\subsubsection{Lukjin - mniejszość chińska a naród tajski}

Radykalnie odmienny był stosunek Wichita do etnicznych Chińczyków. Imigranci z Państwa Środka nie byli zjawiskiem nowym w Azji Południowo-Wschodniej, jednak tendencje globalizacyjne schyłku XIX i początku XX w. skłoniły rzesze poddanych Króla Niebios do opuszczenia ojczyzny i szukania szczęścia z dala od niej, za morzem. W wypadku Syjamu kluczowy był sztywny model społeczeństwa. Aż do 1899 r. funkcjonowała tu pańszczyzna, a dopiero w 1905 r. zniesiono niewolnictwo ${ }^{92}$. Przywiązani do swego pana chłopi i niewolnicy, na których ramionach wypalane były ich dane, nie mogli uczestniczyć w zmodernizowanej gospodarce. I właśnie to stało się jednym z głównych powodów zwiększenia dynamiki imigracji chińskiej - te reguły nie dotyczyły Chińczyków i mogli oni swobodnie pracować w dokach czy manufakturach, których sprawne funkcjonowanie było warunkiem uczestnictwa w światowej gospodarce. Co więcej, nawet po zniesieniu pańszczyzny pogłówne pobierane od Tajów było wyższe od podatków, którymi byli obciążeni Chińczycy. W przypadku pierwszych było to 6 bahtów rocznie, podczas gdy ci drudzy musieli płacić zaledwie 4,37 bahta raz na trzy lata ${ }^{93}$.

\footnotetext{
C. Baker, P. Phongpaichit, A History of Thailand..., s. 126.

92 R. B. Cruikshank, Slavery in Nineteenth Century Siam, „Journal of Siam Society” 1975, vol. 63, nr 2, s. 323-324.

93 J. C. Ingram, Economic Change in Thailand 1850-1970, Stanford 1971, s. 60.
} 
Kasian Tejapira stwierdzit, że tajski nacjonalizm i tajska tożsamość w myśli nacjonalistów z lat 30. XX w. zostały ukonstytuowane na zasadzie opozycji do tożsamości chińskiej $^{94}$. Keerati argumentował natomiast, że tajski nacjonalizm państwowy miał charakter negatywny i pragmatyczny wyłącznie względem Chińczyków (określanych mianem lukjin, odnoszącym się zarówno do imigrantów z Chin, jak też Syjamczyków pochodzenia chińskiego ${ }^{95}$ ), natomiast wobec wszystkich innych niesyjamskich narodów i etniczności pozostawał inkluzyjny i pozytywny ${ }^{96}$.

Należy zaznaczyć, że ta sinofobia tajskiego nacjonalizmu nie wzięła się znikąd i była raczej wtórna wobec zawirowań światowej polityki, aniżeli stanowiła kamień węgielny koncepcji Wichita. Przed japońską inwazją na Chiny stosunek władz syjamskich do Guomindangu i rządu nankińskiego był pozytywny. Chęć rozwoju przyjaźni sino-syjamskiej była na tyle istotna, że w 1937 r. Wichit dodał do swego dramatu o królu Taksinie pieśń o jedności Syjamu i Chin ${ }^{97}$. Sytuacja zmieniła się dopiero po inwazji Japonii na Chiny w 1937 r. Chińska Izba Handlu w Królestwie Syjamu ogłosiła ogólnokrajowy bojkot towarów japońskich. Wydawać by się mogło, że sankcje za zignorowanie wezwania do bojkotu organizacji pozarządowej powinny być minimalne i wynikać z utraty profitów wynikających z przynależności do niej, jednak w tym wypadku konsekwencje były drastyczne: „nieznani sprawcy” zamordowali 61 przedsiębiorców, którzy bojkot zignorowali. Do tego lokalne organizacje chińskie zaczęły organizować wysyłkę wsparcia dla Guomindangu, a 2 tys. chińskich ochotników pojechało na wojnę $e^{98}$.

Trudno byłoby oczekiwać, że władze nie zareagują na tę sytuację. Nałożono restrykcje na szkoły chińskie, zaczęto likwidować chińskie gazety, zamknięto dwa banki, ograniczono imigrację - wszystko to w związku z obiektywnym zagrożeniem, które niosła dla państwa samowola chińskich organizacji (w tym tajnych stowarzyszeń). Bano się, że taka postawa syjamskich Chińczyków wciągnie kraj w wojnę z Japonią 9 .

Król Vajiravudh upowszechnił ukute przez Waringtona Smytha stwierdzenie, iż Chińczycy są Żydami Syjamu ${ }^{100}$, ze względu na swą przedsiębiorczość i kontrolowanie znacznej części handlu i przemysłu w Azji Południowo-Wschodniej. Teza ta została podchwycona przez Wichita w reakcji na opisane zawirowania - odniósł się do niej następująco: Chińczycy nie mogá być z nimi [Żydami - przyp. aut.] porównywani. Oni przybywaja tutaj pracować, ale odsytaja pieniadze z powrotem do swego kraju. W zwiaz-

94 K. Chenpitayaton, „Ethnic Solidarity” Unbounded. Bangkok's Colonial Culture and the Underground Chinese Networks in the Wartime Thailand, A.D. 1927-1958, s. 16, [online] https://www.newschool. edu/WorkArea/DownloadAsset.aspx?id=85600, 16 XII 2016.

95 Szeroko o samym terminie, jak również o losach Chińczyków w Tajlandii, pisał Bogdan Góralczyk. Zob. B. Góralczyk, Zmierzch i brzask. Notes z Bangkoku, Toruń 2009, s. 219-235 oraz Chińczycy $w$ Tajlandii - ciązenie Państwa Środka, „Azja-Pacyfik. Społeczeństwo, Polityka, Gospodarka” 2007, t. 10, s. 204-221.

96 K. Chenpitayaton, „Ethnic Solidarity” Unbounded..., s. 16-17.

97 C. Baker, P. Phongpaichit, A History of Thailand..., s. 129.

98 Tamże, s. 128-129.

99 Tamże.

100 A. W. Jelonek, Wielokulturowość, separatyzm..., s. 143. 
ku z tym możemy powiedzié́, że Chińczycy sa gorsi od Żydów ${ }^{101}$. Jak zauważył Mishra, napisana w 1939 r. przez Wichita Nanchao (nazwa odnosi się do państwa istniejącego w dzisiejszym Yunnanie w Chinach, które zostało podbite w okresie dynastii Yuan; to stamtąd według Dodda i Wichitmatry Tajowie przybyli na południe i miało ono być państwem prototajskim) jest petna jadu wobec etnicznych Chińczyków ${ }^{102}$.

Należy jednak podkreślić, że stosunek tajskiego nacjonalizmu do Chińczyków nie miał podłoża rasowego, tak jak w wypadku niemieckiego nazizmu i jego ludobójczej polityki wobec Żydów. W 1910 r. podczas ceremonii kremacji swego ojca Vajiravudh zwrócił się do chińskiej delegacji słowami: w piersiach Chińczyków i Tajów przez wiele lat bito jedno serce. Jestem wobec tego zdecydowany pomagać wszystkim naszym chińskim braciom, którzy wybrali nasz kraj na swój dom ${ }^{103}$. Umożliwiono więc Chińczykom oficjalną asymilację, od 1939 r. mogli oni wnosić o uznanie ich tajskości, czyli formalne przyznanie obywatelstwa. Musieli zdać rygorystyczny test znajomości języka tajskiego, przyjąć tajskie imię i nazwisko, a także wysłać swe dzieci do tajskiej szkoły. Z takiej opcji skorzystało wielu prominentnych przedsiębiorców ${ }^{104}$. W związku z tym nie można mówić o inherentnej sinofobii tajskiego nacjonalizmu - polityka antychińska była reakcją na zachowanie mniejszości chińskiej, która odmawiała asymilacji i przedkładała swoją lojalność wobec Chin nad lojalność wobec Syjamu. W czasie, gdy wydarzenia związane z wojną sino-japońską zajmowały opinię publiczną w Syjamie i w innych krajach, a Europa była na skraju wojny, doszło do jednego z największych przełomów w dziejach tajskich. 24 czerwca 1939 r. zmieniono nazwę państwa z Królestwo Syjamu na Królestwo Tajlandii. Było to ukoronowanie dzieła budowy tożsamości tajskiej i postulatów Wichita o tworzenie ponadsyjamskiej tożsamości narodowej.

\subsection{5. „Nowoczesny” nacjonalizm schyłku lat 30. XX w.}

W tym samym czasie nacjonalizm Wichita został uzupełniony o poglądy Phibuna, który był głównym inicjatorem bezpośredniego przyjmowania wzorców faszystowskich i nazistowskich w sferze budowania państwa oraz kultu osoby wodza (w miejsce kultu monarszego). Powstał wówczas wzorowany na bushido kodeks honorowy wiratham (na nim z kolei wzorowano następne kodeksy, w tym zaprezentowane we wstępie Dwanaście naczelnych zasad... Prayutha, powtarzających zresztą częśc tez wirathamu) i założono młodzieżowe organizacje paramilitarne ${ }^{105}$. Ten kierunek rozwoju państwa był zdaniem Wichita jak najbardziej słuszny. Jak już wspomniano, jego wizja narodu tajskiego była bardzo szeroka, wykraczała poza granicę rodziny języków tai-kadai. Twierdził, że Birmańczycy, Wietnamczycy, Khmerzy i Malajowie byli pierwotnie odmianami Tajów ${ }^{106}$.

\footnotetext{
101 C. Baker, P. Phongpaichit, A History of Thailand..., s. 129.

102 P. P. Mishra, The History of Thailand..., s. 111.

103 A. W. Jelonek, Wielokulturowość, separatyzm..., s. 142.

104 C. Baker, P. Phongpaichit, A History of Thailand..., s. 129.

105 P. P. Mishra, The History of Thailand..., s. 111.

106 C. Baker, P. Phongpaichit, A History of Thailand..., s. 131.
} 
Gdy obecna wojna się skończy, na świecie nie pozostanie żaden maty naród, wszystkie potacza się w większe. Sq zatem dla nas dwa wyjścia - albo zostać Potega, albo dać się zjeść innej Potędze - mówił Wichit ${ }^{107}$, uzasadniając potrzebę ekspansjonizmu. To też był jeden z powodów, dla których chciano tworzyć nową, szerszą tożsamość narodową. Tylko zjednoczenie całej kontynentalnej Azji Południowo-Wschodniej miało pozwolić Tajlandii na suwerenność i uniknąć losu kolonii. Strach przed byciem podporządkowanym, który towarzyszył politykom syjamskim od XIX w., nie zniknął, wręcz przeciwnie - wobec agresywnej polityki mocarstw takich jak Japonia czy Niemcy postanowiono wykorzystać ich idee w celu budowy silnego państwa, zamiast sprzymierzać się przeciwko nim. Wichit w pełni zgodził się tym samym z dwoma naczelnymi tezami Treitschkego: państwo ma prawo do dyktowania swojej woli mniejszym organizmom społecznym i politycznym, a także musi budować wspólnotę, abstrahując od różnic lingwistycznych i genetycznych, tworzyć nowy naród oparty na swoistym „złudzeniu”, micie założycielskim. W tym wypadku miała to być antyczna „tajskość”, starsza od Chin wspólnota ludów od Yunnanu po Singapur.

Polityka taizacji, która miała ów szeroki i wielki naród stworzyć, oparta była na czterech filarach: antyrojalizmie (świętem państwowym stała się rocznica rewolucji z 1932 r., znacznie osłabiono wpływ dworu na sanghę buddyjską i zlikwidowano część tytułów wywodzących się z czasów przedrewolucyjnych), promocji „tajskiego standardowego" (czyli skodyfikowanej wersji języka syjamskiego), jedności narodowej (specjalne komisje zakazały używania w piosenkach ludowych odwołań do etniczności innej niż tajska, a więc nie można było już śpiewać o tym, ze jest się Laotańczykiem czy Syjamczykiem) i postępowości, która miała opierać się na noszeniu zachodnich strojów (tradycyjne stroje zostały zakazane, mężczyźni mieli nosić spodnie, a kobiety spódnice i kapelusze), używaniu widelca i noża, ustawianiu się w kolejkach, a nawet całowaniu żony przed wyjściem do pracy ${ }^{108}$.

Jak zatem widać, wbrew postulatowi „wszyscy jesteśmy Tajami”, nie było miejsca na politykę na zasadzie in varietate concordia. Ostatecznie taizacja oznaczała politykę syjamizacji, a więc poza warstwą postulatywną sama taizacja nie różniła się od koncepcji nacjonalizmu wedle króla Vajiravudha. Znowu - była to propozycja jak u Treitschkego, stosowania swoistego Kulturkampfu względem grup mniejszościowych. Oczywistą różnicą w stosunku do rojalistycznego nacjonalizmu syjamskiego była silna antyrojalistyczność. Niemniej nie stanowiła ona aż tak istotnego aspektu tajskiego nacjonalizmu, jej obecność związana była z absolutną słabością obozu królewskiego i samego dworu król nie dość, że był dzieckiem, to na dodatek rezydował w Szwajcarii.

Sytuacja zmieniła się dopiero po dojściu do władzy następcy przedwcześnie zmarłego króla Mahidola, Bhumibola Adulyadeja (był królem w latach 1946-2016). Wtedy też nowoczesny nacjonalizm Wichita połączony został z silnym rojalizmem poprzez rozwój komplementarnej wobec niego koncepcji „tajskości” i relacji król-naród autorstwa Kukrita Pramoja. Głosiła ona „polityczną ciszę” i absolutną uległość narodu wobec wła-

107 Tamże.

108 Tamże, s. 131-132. 
dzy. Widać w niej silne inspiracje ideami Vajiravudha, nie odrzucała jednak idei zaproponowanych przez Wichita. W latach 90. XX w. nastąpił proces demokratyzacji i postanowiono odejść od kukritowskiej „ciszy politycznej”. W ramach nowego, otwartego dyskursu zrehabilitowano oskarżanego o tendencje komunistyczne Pridiego Banomyonga, na cenzurowanym przestała być twórczość polityka i myśliciela Pueya Ungphakorna. Ich dziedzictwo polityczne zostało zaadaptowane przez część klasy politycznej.

\section{PODSUMOWANIE}

Ideologia Wichita, która ewoluowała za jego życia, przetrwała do dziś. Bez wątpienia pozostaje on najbardziej wpływowym myślicielem politycznym w historii Tajlandii. Ukształtowana przez niego „tajskość” jest silna i żywa, zaś nieśmiałe próby legitymizacji lokalnych tożsamości (szczególnie Lanna i isaańskiej) nie są w stanie zagrozić tożsamości tajskiej jako dominującej i jednoczącej obywateli Tajlandii. Ważnym wyjątkiem w tej kwestii są jednak Malajowie, których świadomość odrębności językowej i etnicznej jest silna i artykułowana na różne sposoby, w tym przez działalność organizacji terrorystycznych. Konflikt etnoreligijny na południowych rubieżach kraju jest aktywny i rocznie w zamachach ginie kilkadziesiąt osób. Granice wytyczone na mocy traktatu z Pangkoru z 1874 r., który został na Syjamie wymuszony przez Zjednoczone Królestwo, przebiegają w taki sposób, że duża społeczność malajska zamieszkuje obszar południowych prowincji (dawny Sułtanat Pattani) i marzy o niepodległości.

Uzasadnione jest twierdzenie, że „szeroka” koncepcja tajskości poniosła klęskę ostatecznie można ją odnieść wyłącznie do heterogenicznej grupy ludów posługujących się językami tai-kadai, w tym zasymilowanych obywateli pochodzenia chińskiego. Mimo popularności króla Bhumibola oraz bezwzględnego oddania jego poddanych trudno mówić o tym, że to koncepcja "tajskości” i chat Thai Vajiravudha okazały się bardziej wpływowe niż analogiczne idee Wichita. Pierwszy, najbardziej znamienny i doniosły, punkt Dwunastu naczelnych zasad... Prayutha mówi o trzech filarach: narodzie, religii i monarchii. Motyw ten pojawiał się we wszystkich koncepcjach narodu tajskiego, jednak nadanie prymatu wspólnocie narodowej było zasługą Wichita. To, że w zasadach Prayutha właśnie naród jest na pierwszym miejscu, przed religią i monarchią, nie wydaje się przypadkowe.

Pomimo ciągłych prób redefiniowania „tajskości” to właśnie szlak, który wytyczył Wichit, okazał się najbardziej trwały i stanowi punkt odniesienia dla kolejnych „architektów" starających się zmienić kształt tajskiego społeczeństwa. Inkluzyjna polityka względem społeczności peryferyjnych, asymilacja Chińczyków oraz umocnienie narodu w trójkącie władzy naród-religia-król, wręcz umieszczenie go u szczytu tej konfiguracji (w domyśle jest to oczywiście naród reprezentowany przez elity, które mają nie być słabsze od władzy religijnej czy monarszej), to trwałe zdobycze Wichita, które przetrwały do dziś. Z całą pewnością można stwierdzić, że jego wpływ na dzieje Tajlandii był niebagatelny, a jako myśliciel i pisarz jest na nowo odkrywany i doceniany przez kolejne pokolenia Tajów. 


\section{BIBLIOGRAFIA}

\section{Publikacje drukowane:}

\section{Literatura źródłowa:}

Departament Stanu USA, Papers relating to the foreign relations of the United States, with the annual message of the president transmitted to Congress December 5, 1905, Washington 1905.

Mouhot H., Travels in the Central Parts of Indo-China (Siam), Cambodia, and Laos, during the Years 1858, 1859, and 1860, vol. 2, London 1864.

Traktat syjamsko-brytyjski podpisany w Bangkoku dnia 10 marca 1909 r.

Traktat syjamsko-francuski w sprawie delimitacji granicy między francuskimi i syjamskimi terytoriami oraz ustanowienia systemu jurysdykcyjnego z dnia 13 lutego $1904 \mathrm{r}$.

\section{Literatura pomocnicza:}

- monografie i opracowania:

Baker Ch., Phongpaichit P., A History of Thailand, Cambridge 2014.

Barmé S., Luang Wichit Wathakan and the Creation of Thai Identity, Singapore 1993.

Chandler D. P., History of Cambodia, Boulder 2008.

Evans G., The Short History of Laos. The Land in Between, Crows Nest 2002.

Haberkorn T., Revolution Interrupted. Farmers, Students, Law, and Violence in Northern Thailand, Madison 2011.

Herington J. [i in.], Sociolinguistic Survey of Northern Thai, SIL International, Electronic Survey Report 2013-009, Dallas 2013.

Ingram J. C., Economic Change in Thailand 1850-1970, Stanford 1971.

Jelonek A. W., Wielokulturowość, separatyzm i budowa państwa narodowego w Tajlandii, Kraków 2011.

Kuhonta E. M., The Institutional Imperative. The Politics of Equitable Development in Southeast Asia, Stanford 2011.

Lawrence P., Nacjonalizm. Historia i teoria, przeł. P. K. Frankowski, Warszawa 2007.

Lieberman V., Strange Parallels. Southeast Asia in Global Context, c. 800-1830, vol. 1: Integration on the Mainland, Cambridge 2003.

Mishra P. P., The History of Thailand, Santa Barbara 2010.

Muller G., Colonial Cambodia's „Bad Frenchman”. The Rise of French Rule and Life of Thomas Caraman, 1840-87, London-New York 2006.

Peleggi M., Thailand. The Worldly Kingdom, Singapore-London 2007.

Penth H., A Brief History of Lanna. Northern Thailand from Past to Present, Chiang Mai 2004.

Schliesinger J., Tai Groups of Thailand, vol. 1: Introduction and Overview, Bangkok 2014.

Smith A. D., National Identity, Reno 1999.

Smith H. E., Nieminen G. S., Win M. K., Historical Dictionary of Thailand, Lanham 2005.

Stowe J. A., Siam Becomes Thailand. A Story of Intrigue, London 1991.

Stuart-Fox M., A Short History of China and Southeast Asia. Tribute, Trade and Influence, Crows Nest 2003. 
Tuck P., The French Wolf and the Siamese Lamb. The French Threat to Siamese Independence, 1858-1907, Bangkok 1995.

- rozdziały w pracach zbiorowych:

na Pombejra D., Siam and the West, Kingdom of, [w:] Encyclopedia of Western Colonialism since 1450, red. T. Benjamin, Detroit 2007.

Tarling N., The Establishment of the Colonial Regimes, [w:] Cambridge History of Southeast Asia, vol. 2: The Nineteenth and Twentieth Centuries, red. tenże, Cambridge 1994.

- artykuty w czasopismach naukowych:

Briggs L. P., The Treaty of March 23, 1907 Between France and Siam and the Return of Battambang and Angkor to Cambodia, „The Far Eastern Quarterly” 1946, vol. 5, nr 4, [online] https://dx.doi.org/10.2307/2049791.

Cruikshank R. B., Slavery in Nineteenth Century Siam, „Journal of Siam Society” 1975, vol. 63, nr 2.

Draper J., Introducing Multilingual Thai-Isan-English Signage in a Thai University, „Journal of Lao Studies" 2013, vol. 4, nr 1.

Góralczyk B., Chińczycy w Tajlandii-ciążenie Państwa Środka, „Azja-Pacyfik. Społeczeństwo, Polityka, Gospodarka” 2007, t. 10.

McCargo D., Hongladarom K., Contesting Isan-ness: Discourses of Politics and Identity in Northeast Thailand, „Asian Ethnicity” 2004, vol. 5, nr 2, [online] https://dx.doi.org/10.10 80/1463136042000221898.

Meyer M. J., The Idea of the Social in the Thought of Three Thai Politicians and Intellectuals in the mid-20th Century, „Journal of Humanities and Social Sciences” 2010, nr 2.

Meyers D., Siam under Siege (1893-1902). Modern Thailand's Decisive Decade, from the "Paknam Incident" to the First Flowering of the "Chakri Reformation”, "Journal of the Siam Society" 1994, vol. 82, pt. 2.

Phattharathanit S., Identity Maintenance in Lanna (Northern Thai), "Journal of the Southeast Asian Linguistics Society” 2012, vol. 5.

Vickery M., Thai Regional Elites and the Reforms of King Chulalongkorn, „The Journal of Asian Studies" 1970, vol. 29, nr 4, [online] https://dx.doi.org/10.2307/2943093.

\section{Publikacje elektroniczne:}

\section{Literatura źródłowa:}

The Twelve Core Values for a Stronger Thailand, National News Bureau of Thailand, [online] http://nwnt.prd.go.th/link/en/Core_Values.

\section{Literatura pomocnicza:}

- monografie i opracowania:

Chenpitayaton K., "Ethnic Solidarity” Unbounded. Bangkok's Colonial Culture and the Underground Chinese Networks in the Wartime Thailand, A.D. 1927-1958, [online] https:// www.newschool.edu/WorkArea/DownloadAsset.aspx ?id=85600.

Sattayanurak S., The Construction of Mainstream Thought on "Thainess" and the "Truth" Constructed by „Thainess”, dysertacja doktorska, Department of History, Faculty of Humanities, 
Chiang Mai University, Chiang Mai 2008, [online] http://www.fringer.org/wp-content/ writings/thainess-eng.pdf.

- artykuły prasowe:

Thailand to Celebrate „2015 Discover Thainess” Campaign with Grand Opening Celebration, „TAT News”, 5 I 2015, [online] http://www.tatnews.org/thailand-to-celebrate-\%E2\%80 \%9C2015-discover-thainess\%E2\%80\%9D-campaign-with-grand-opening-celebration.

Thai Students Required to Recite Prayuth's 12 Core Values Daily, „Asian Correspondent”, 22 IX 2014, [online] https://asiancorrespondent.com/2014/09/all-thai-students-required-to-recitedaily-prayuths-12-core-values.

Patryk TOMALA, magister prawa i studiów azjatyckich, doktorant na Wydziale Studiów Międzynarodowych i Politycznych UJ. Do jego głównych zainteresowań należą ideologie i ruchy masowe oraz kultura polityczna i prawna krajów Azji Południowo-Wschodniej. 